\title{
Assessment of the quality of the Densu river using multicriterial analysis and water quality index
}

\author{
Samuel Anim Ofosu ${ }^{1,2} \cdot$ Kwaku A. Adjei ${ }^{1,3} \cdot$ Samuel Nii Odai ${ }^{1,3}$
}

Received: 24 January 2020 / Accepted: 18 October 2021 / Published online: 6 November 2021

(c) The Author(s) 2021

\begin{abstract}
The natural resources, especially water in the Densu river basin, play significant roles in the socio-economic development of Ghana. The purpose of this study was to analyse the water quality of the Densu river using water quality index (WQI) and multivariate techniques. In this study, physico-chemical and bacteriological parameters were measured from surface water samples taken from eight (8) sampling stations in the study area. water quality index and multivariate techniques such as hierarchical cluster analysis and principal component analysis were utilized in the analysis of surface water quality data. The results indicated that the average WQI of the Densu river for the two sampling periods was sixty-one (61) which is classified as Medium, based on the Solway WQI index. The $\mathrm{pH}$ levels of all the samples were within allowable limits of World Health Organization (WHO) guidelines. All the sampling stations for the two seasonal periods had bacteriological parameters higher than WHO guidelines, making the samples unsuitable for most domestic uses. The study revealed that six (6) principal components accounted for about $97 \%$ of the total variance of dataset and three (3) spatial clusters were classified. This research has provided the basis for applying both WQI and multivariate techniques in analysing and classifying water quality in a river basin.
\end{abstract}

Keywords Freshwater $\cdot$ Parameters $\cdot$ Multivariate $\cdot$ Loadings $\cdot$ Variations

$\begin{array}{ll}\text { Abbreviations } \\ \text { BOD } & \text { Biochemical oxygen demand } \\ \text { CA } & \text { Cluster analysis } \\ \text { COD } & \text { Chemical oxygen demand } \\ \text { DA } & \text { Discriminant analysis } \\ \text { DO } & \text { Dissolved oxygen } \\ \text { EC } & \text { Electrical conductivity } \\ \text { GWCL } & \text { Ghana water company limited } \\ \text { HCA } & \text { Hierarchical cluster analysis } \\ \text { PCA } & \text { Principal component analysis } \\ \text { TDS } & \text { Total dissolved solids } \\ \text { TSS } & \text { Total suspended solids }\end{array}$

Samuel Anim Ofosu

ofosu@ktu.edu.gh

1 Regional Water and Environmental Sanitation Centre, Kumasi, Ghana

2 Present Address: Department of Civil Engineering, Koforidua Technical University, P O Box KF 981, Koforidua, Ghana

3 Department of Civil Engineering, Kwame Nkrumah University of Science and Technology, Kumasi, Ghana
WHO World Health Organization

WQI Water quality index

\section{Introduction}

Freshwater resources have come under the spotlight due to quantity and quality reasons. Surface water resources have been noted to be extremely sensitive to changing natural processes such as rainfall, temperature, forest cover and ultimately climate change (Li et al. 2009; Usman et al. 2014; Wang et al. 2018). These changes in natural environmental processes are greatly influenced by anthropogenic activities that include growth in urban areas and agricultural activities (Khatri and Tyagi 2015; Bouguerne et al. 2017; Verma et al. 2019).

These anthropogenic activities have the potential of causing the degradation of surface water resources. Pollutants from urban areas, industries and agricultural lands make the surface water resources vulnerable (Satterthwaite et al. 2010; Huang et al. 2018; Salerno et al. 2018). High concentrations of toxic materials from pollution sources could lead to diverse environmental challenges such as loss of 
biodiversity, changing the aesthetics of environment around water bodies, algal bloom, loss of flora and fauna (Mishra 2010; Kengnal et al. 2015; Kumar and Ranjan 2017).

Rivers in catchments with extensive agricultural and built-up land-use practises increased pollution inputs (Sickman et al. 2007) in addition to varying the concentrations of nitrogen, phosphorus and other agro-chemical applications (Easton et al. 2007; Khalil and Ouarda 2009).

Freshwater resource availability is the most critical natural resource issue for the whole of humanity (Hinrichsen and Tacio 2002). The freshwater shortage has been mentioned as one of the major emergencies of the twenty-first century (Srinivasan, et al. 2012). In view of the challenges emanating from freshwater scarcity, there has been a conscious effort at ensuring water security for both humans and biodiversity (Vörösmarty, et al. 2010).

Moreover, as a result of the spatial and temporal disparities in water quality, monitoring programmes usually encompass a great number of physico-chemical parameters. Regular water quality sampling periods at various sites are essential for the provision of reliable surface water quality profiles for a given study area (Kengnal et al. 2015; Anteneh et al. 2018; Ustaoğlu and Tepe 2018).

As the economies of developing countries advance, there is a resultant extensive land use/land cover changes (Kanianska 2015; Salerno et al. 2018), degradation of water resources and the environment (Zhao et al. 2011). These environmental dilapidations impede sustainable development and compromise livelihoods of human populations (Xu et al. 2009; Huang et al. 2010; Fitch et al. 2016).

Detailed and accurate assessment of the extent of surface water pollution is relatively difficult due to the varied processes and intricate phenomena depicting these environmental conditions (Huang et al. 2010). The physico-chemical and bacteriological analysis is required to effectively assess the different procedures and mechanisms involved in polluting freshwater bodies (Şener et al. 2017; Emami and Koch 2018; Wu et al. 2018).

Physico-chemical parameters such as $\mathrm{pH}$, turbidity, temperature, total dissolved solids, electrical conductivity (EC) and dissolved oxygen (DO) levels are the most frequently used pointers of water quality (Attua et al. 2014).

Numerous studies have recognized some procedures used for assessing water quality (Tian et al. 2019). These methods include an all-inclusive assessment method referred to as the water quality index (WQI). This method is a mathematical tool used to aggregate several physico-chemical and bacteriological parameters of water quality into a single figure (Abbasi and Abbasi 2012; Bouguerne et al. 2017; Şener et al. 2017). Different WQI scales have been adopted for evaluating water quality (Abbasi and Abbasi 2012; Samadi et al. 2015; Ewaid and Abed 2017; Şener et al. 2017). The
WQI values usually range between zero (0) and a hundred (100).

Water quality index (WQI) is a very convenient and effective technique for calculating the suitability of water quality and useful tool for disseminating the evidence on the general quality of water of surface water (Akoteyon et al. 2011). WQI replicates and aggregates the amalgamated influence of diverse water quality parameters. Suitability of both surface and groundwater resources for the human is the viewpoint of WQI (Akoteyon et al. 2011; Abyaneh et al. 2018; Tian et al. 2019).

The application of multidimensional or multivariate data analysis procedures is increasingly becoming very prevalent in environmental studies, encompassing both measurement and monitoring (Oketola et al. 2013). The most common multivariate data analysis procedures used are principal component analysis (PCA), cluster analysis (CA) and discriminant analysis (DA) (Badalians Gholikandi et al. 2011; Oketola et al. 2013; Verma et al. 2019). These multivariate analysis tools identify important components that explain the variations in water quality for a study area (Fathy et al. 2012; Kebede and Kebedee 2012; Garcia et al. 2017).

The adoption of diverse multivariate methods, such as PCA and CA, for the explanation of water quality datasets provides an enhanced understanding and subsequent correlation of water quality and environmental status (Moyel 2014). The multivariate techniques further allow the identification of probable factors that could impact water quality whilst serving as a valuable method for the management of water pollution problems (Shrestha and Kazama 2007; Moyel 2014; Park et al 2014; Kengnal et al. 2015; Mitra et al. 2018).

PCA and CA have been used extensively to analyse water quality across the globe (Parinet et al. 2004; Mustapha and Abdu 2012; Gomes et al. 2014). According to (Bidhendi et al. 2013), using PCA and CA techniques provided a means for inferring intricate water quality datasets and to help in the design of monitoring networks.

In this study, multivariate statistical techniques were used for analysing the surface water quality of the Densu river at eight sampling stations along the river. The main objective of this study was to use multivariate techniques to classify the water quality of the Densu river basin. This study further seeks to identify the parameters accountable for spatial variations in the quality of the Densu river. 


\section{Materials and methods}

\section{Study area}

The Densu river and its network of streams constitute one of Ghana's most exploited coastal basins. The basin is located between latitude $5^{\circ} 33^{\prime} \mathrm{N}-5^{\circ} 40^{\prime} \mathrm{N}$ and longitude $0^{\circ} 20^{\prime} W-0^{\circ} 24^{\prime} W$. The basin covers an estimated land area of $2600 \mathrm{~km}^{2}$.

The Densu basin (Fig. 1) is noted for its immense socioeconomic importance to Ghana. The Densu river provides water for the Western sectors of Accra through the Weija Treatment plant (Nee-Whang 1999; Obeng 2005; Asamoah et al. 2008; Owusu 2012; Antwi-Agyakwa 2014; Nyamekye et al. 2016).

The river takes its source from the Atwiredu mountains and flows for about $120 \mathrm{~km}$ into the Weija lake/reservoir before discharging into the Gulf of Guinea. The Densu Delta Ramsar site is located at the estuary of the river, west of Accra (WRC 2014). The major tributaries of the river are Mame, Kuia, Adeiso, Nsaki and Dobro, which are themselves fed by a network of streams (Adomako et. al. 2011a).

The Ghana Water Company Limited (GWCL) supplies around $190,000 \mathrm{~m}^{3}$ of treated water on daily basis, from the Densu river and its tributaries. Weija treatment plant accounts for about $90 \%$ of total water treated along the Densu river. The Weija treatment plant supplies treated water to Kasoa and its environs in the Central Region of
Fig. 1 Densu river basin with water quality sampling stations

\section{Water Sampling Stations of the Densu Basin}

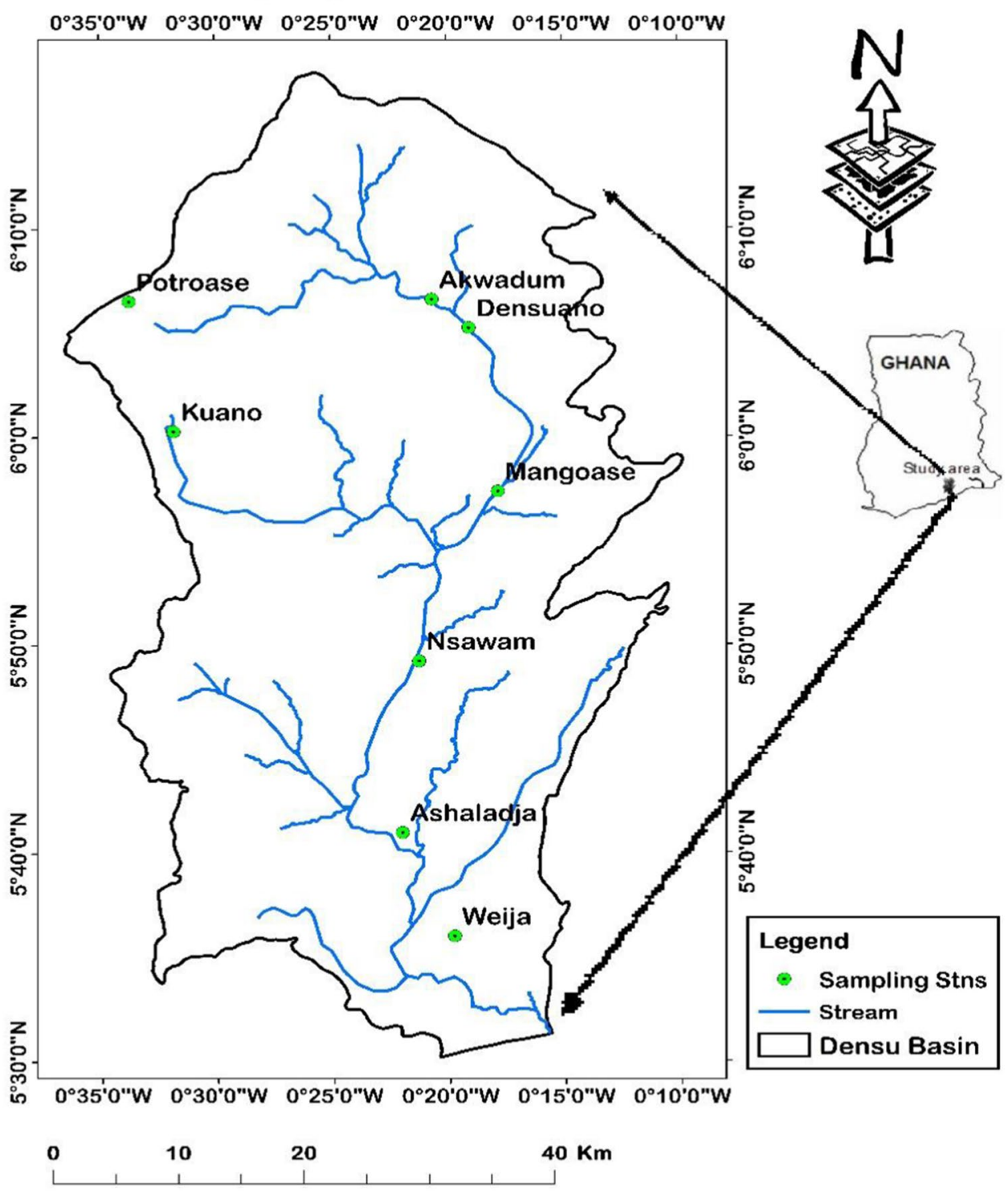


Ghana, Industrial and commercial hub in Accra (Alfa 2010; Adank et al. 2011; Alfa et al. 2011; Kasei et al. 2014; Water Resources Commission 2014; Schep et al. 2016).

The main vegetation types identified in the basin can be classified into three. The Northern portion of the basin is generally well-forested land, and the middle section is noted by scattered trees, shrubs and predominantly grassland. The downstream of the basin forms part of the coastal savannah zone (WRC-Ghana 2007; Alfa et al. 2011).

The basin is characterized by relatively high temperatures throughout the year, with a mean annual temperature around $28^{\circ} \mathrm{C}$. March and April are considered the hottest periods, with average temperatures of about $32{ }^{\circ} \mathrm{C}$, whilst August is the coolest month, with a temperature around $24{ }^{\circ} \mathrm{C}$ (Water Resources Commission 2014).

The major rainy period in the basin ranges from late February to late July with the peak in June, while the minor rainfall season occurs between August and late October (Water Resources Commission 2014; Nyamekye et al. 2016). The mean annual rainfall ranges between 450 and $1900 \mathrm{~mm}$ (Dickson Adomako et al. 2011a, b).

\section{Sampling and analytical procedures}

Surface water samples were collected during dry and wet seasons from eight (8) sampling sites using clean and disinfected sampling bottles. The transportation of samples to the laboratory as well as the preservation of the samples was in accordance with standard procedures used by Abbasi and Abbasi (2012), Mahapatra et al. (2012); Ewaid and Abed (2017) and Şener et al. (2017).

Temperature (T), DO, $\mathrm{pH}$ and EC were measured in situ by means of thermometer and the Hach 2100AN model workbench turbidimeter (Dharmendra et al. 2018). Volumetric titrimetry was used to measure calcium $\left(\mathrm{Ca}^{2+}\right)$, magnesium $\left(\mathrm{Mg}^{2+}\right)$ and chloride $\left(\mathrm{Cl}^{-}\right)$ions (Zeinalzadeh and Rezaei 2017). Spectrophotometer was used to ascertain the sulphate ions ( $\mathrm{SO}^{-2}$ ) in the samples (Anteneh et al. 2018). Turbidimetric method was used to analyse the level of turbidity of the samples. Sodium and potassium ions were measured by means of the flame photometry method (Zeinalzadeh and Rezaei 2017). Ammoniac $\left(\mathrm{NH}_{4}{ }^{+}\right)$and nitrate nitrogen $\left(\mathrm{NO}^{-3}\right)$ were determined using phenate and cadmium reduction methods, respectively (Effendi et al. 2015). All water quality analyses were executed based on standard procedures for the assessment of water (Abbasi and Abbasi 2012).

The water samples for dry season were taken from December 2017 to February 2018. The wet season sampling was done between June 2017 and August 2017. These periods spanned the seasonal variations in the basin. The sampling stations (Fig. 1) were spread across the basin, i.e. from the upstream of the basin to the downstream. This helped to

assess the quality of the Densu river as it traverses the length of the basin to the outfall.

\section{Statistical analysis}

Thirty-three (33) physico-chemical and bacteriological parameters were measured from the water samples. The measured water quality parameters were analysed and subjected to statistical scrutiny using water quality index (WQI), cluster analysis (CA) and principal component analysis (PCA).

Water quality parameters such as $\mathrm{pH}$, colour, electrical conductivity (EC), turbidity, total hardness, calcium hardness, magnesium hardness, chloride, biochemical oxygen demand (BOD), dissolved oxygen (DO), total dissolved solids (TDS), total suspended solids (TSS), total irons, phosphates, copper, calcium, manganese, zinc, magnesium, fluoride, Nitrate-nitrogen, ammonia-nitrogen, nitrate and sulphate were analysed. Heavy metals such as cyanide, mercury, arsenic, chromium and cadmium were tested. Bacteriological parameters such as total coliforms, heterotrophic bacteria counts and E. coli were also tested.

\section{Water Quality Index}

Water quality index (WQI) has been characterized as the main measure for classification of the quality of surface water based on the usage of standard parameters that are applied during surface water characterization (Kannel et al. 2007; Sánchez et al. 2007).

Across the globe, numerous research institutions have formulated water quality indices as a means for assessing the quality of water samples. Notable amongst the water quality indices include the US National Sanitation Foundation water quality index (NSFWQI), the Canadian Council of Ministers of the Environment water quality index (CCMEWQI), the Oregon water quality index (OWQI), the Solway River Purification Board (RBP) Weighted water quality index and the British-Columbia water quality index

Table 1 Water quality index classification

\begin{tabular}{lll}
\hline Class & WQI range & $\begin{array}{l}\text { Rating } \\
\text { of water } \\
\text { quality }\end{array}$ \\
\hline I & $91-100$ & Excellent \\
II & $71-90$ & Good \\
III & $51-70$ & Medium \\
IV & $26-50$ & Bad \\
V & $0-25$ & Very bad \\
\hline
\end{tabular}

Source (Zeinalzadeh and Rezaei 2017) 
(BCWQI) (Abbasi and Abbasi 2012; Şener et al. 2017; Zeinalzadeh and Rezaei 2017).

The NSFWQI was formulated to provide a standardized technique for comparing the quality of various water quality samples from different sources in a study (Şener et al. 2017). The classification of the water quality index was based on Table 1.

A study conducted on the water quality index of the Densu river (Amoako et al. 2010) adopted the Solway River Purification Board (RBP) Weighted water quality index. This was calculated using Eq. 1:

Solway_WQI $=\frac{1}{100}\left(\sum_{i=1}^{n} q_{i} w_{i}\right)^{2}$

where $q_{i}$ represents the quality of water samples of the nth parameter, and $w_{i}$ signifies the weighting of the nth parameter.

\section{Cluster analysis}

Cluster analysis was used for exploratory analysis of data. These method groups variables and parameters into clusters based on identified levels of similarities (or dissimilarities). Hence, each cluster signifies a definite process (Zhao and Cui 2009). The characteristics of each identified class are not known but may be evaluated from the management of the data used (Shrestha and Kazama 2007). The hierarchical cluster analysis (HCA) was applied for surface water quality parameters using SPSS and Gretl.

\section{Principal Component Analysis (PCA)}

PCA is a great multivariate statistical analysis technique which has the capacity to reduce the dimensionality of water quality data comprising of large number of related variables, while maintaining as much as possible, the variability existing in the data (Ouyang 2005; Garcia et al. 2017; Tripathi and Singal 2019).

PCA is basically used to classify patterns in data, bring out their similarities and differences through the reduction of the number of dimensions and related complexity identified in the data matrix of the variables (Arslan 2009; Le et al. 2017).

In PCA, a dataset comprising correlated parameters is transformed into another dataset containing orthogonal and unrelated parameters termed as principal components (Olsen et al. 2012; Le et al. 2017; Mena-Rivera et al. 2017).

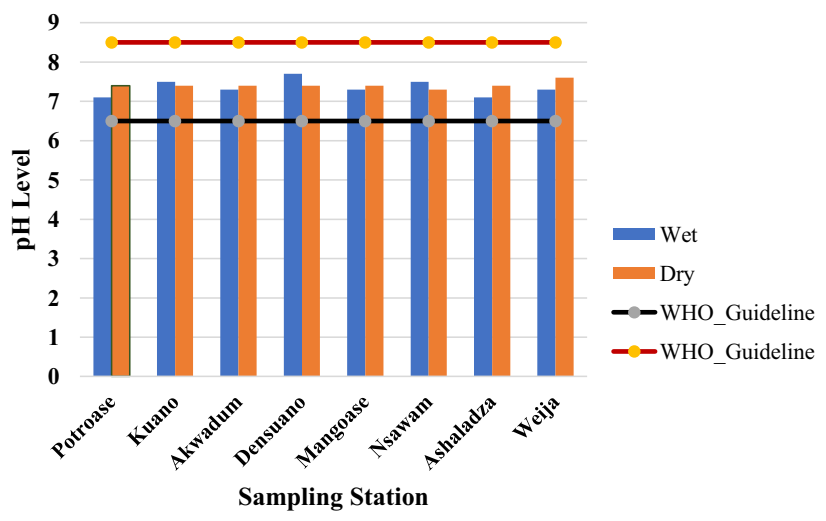

Fig. 2 Average $\mathrm{pH}$ for the sampling seasons

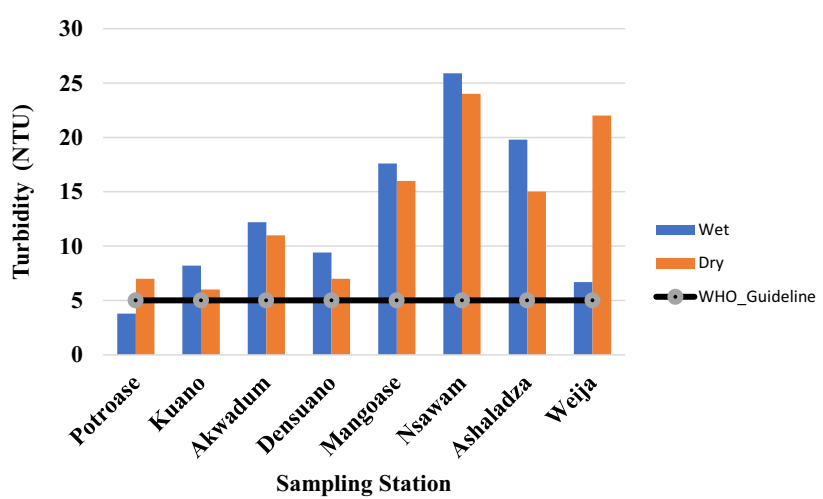

Fig. 3 Turbidity for west and dry seasons

Algebraically, for $\mathrm{n}$ water quality parameters, $x_{1}, x_{2}, x_{3}, \ldots, x_{n}$ and $\mathrm{j}$ sample number, principal components are determined using Eq. 2

$z_{i j}=x_{1 \mathrm{jai} 1}+x_{2 \mathrm{jai} 2}+x_{3 \mathrm{jai} 3}+\cdots+x_{\text {njain }}$

where $a$ represents the loading for each parameter of extracted principal components, $z$ represents the principal component score, and $i$ represents the amount of extracted principal components.

The results from the PCA are linear functions arising from the original variables. This implies that the summation of their variances is equivalent to that of their inventive variables (Olsen et al. 2012; Le et al. 2017). 


\section{Results and discussion}

\section{Physico-chemical quality analysis}

The $\mathrm{pH}$ of the water samples during the study period ranged from 7.1 to 7.7. These $\mathrm{pH}$ values were with the WHO water guidelines (World Health Organization 2017).

The $\mathrm{pH}$ values during the study were all within the recommended levels by the WHO (6.5-8.5). During the wet seasons, the $\mathrm{pH}$ for Densuano was the highest (7.7), whilst Weija had the highest $\mathrm{pH}$ values (7.6) for the dry season. These results (Fig. 2) are in line with earlier studies in the Densu basin (Asante et al. 2008; Adomako 2010; WRC 2014; Osei et al. 2016).

Higher turbidity results (Fig. 3) were recorded during the rainy seasons apart from Potroase and Weija that recorded relatively lower turbidity levels during the wet season. Potroase sampling point had low runoff points discharging into the stream. Weija sampling station was close to the Weija reservoir, and hence, there is the possibility for some level of settlement of suspended solids and eroded matter that may influence turbidity levels.

Apart from Potroase (wet season), all the other sampling stations had their turbidity levels higher than the WHO guidelines. The low levels of turbidity for Potroase in the wet season were due to less volume of runoff joining the Densu river at the sampling point. The forest cover and shrubs tend to also retard the movement of eroded materials into the stream, especially at the Potroase sampling site.

The Weija sampling station was around the Weija reservoir. There was the likelihood that some level of settlement of suspended solids and eroded materials may have taken place, thereby showing lower levels of turbidity.

The high rate of turbidity may be attributed to the topography of the basin and other anthropogenic activities being

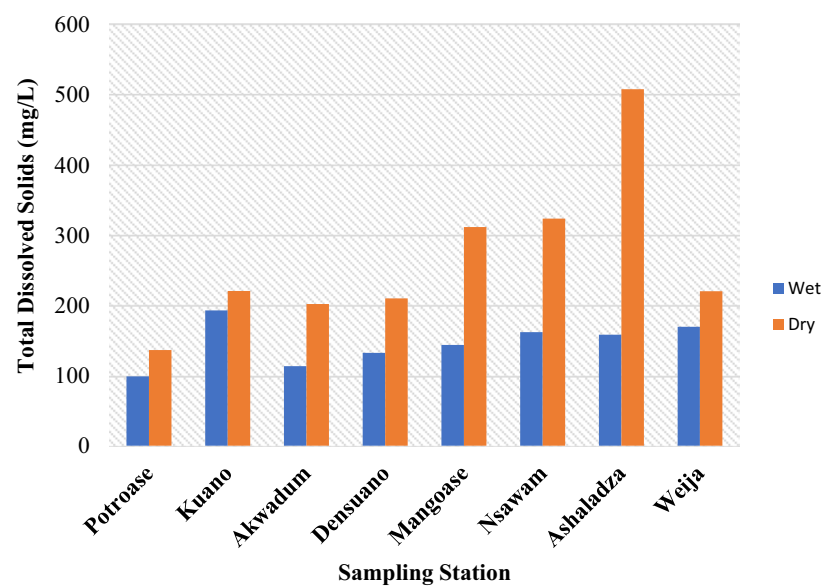

Fig. 4 Total dissolved solids for wet and dry seasons undertaken in various parts of the basin. These activities become high triggers for erosion and runoff into nearby streams.

The turbidity of a stream may be attributed to the clay particles within the eroded soil of the catchment area (Rubio-Arias et al. 2012). The dissolution of soil material especially during rainy seasons and ensuing runoff end in streams thereby affecting the turbidity of the receiving streams.

Research has confirmed that high turbidity levels influence negatively, the aesthetics of streams and waterbodies. Thus, recreation, tourism and cost of water treatment may be affected negatively (Memon et al. 2011; World Health Organization (WHO) 2017; Bouckaert et al. 2018).

Total dissolved solids (TDS) were higher in the dry season for the sampling points, relative to the wet season (Fig. 4). This result could be linked to the dilution resulting from increased runoff (Pullanikkatil et al. 2015).

The total dissolved solids of the Densu river varied from upstream towards downstream (Fig. 4) due to river bank cultivation, sand mining, soil disturbance and construction activities close to the river (Pullanikkatil et al. 2015). The TDS for wet season ranged between 99 to $192.8 \mathrm{mg} / \mathrm{l}$, while the dry season values ranged between 136.5 and $508 \mathrm{mg} / \mathrm{l}$.

The EC results for wet seasons were greater than the dry season readings (Fig. 5). The results ranged between 216 to $417 \mathrm{microS} / \mathrm{cm}$ for wet season and 27.3-101.6 microS/ $\mathrm{cm}$ for dry seasons. These results were corroborated by an earlier studies (Hoque et al. 2013; Makwe and Chup 2013; Nienie et al. 2017) which stated that EC values are higher in the wet seasons compared to the dry seasons.

According to the WHO guidelines for safe and healthy water (World Health Organization 2011, 2017), there should be no identifiable bacteriological parameter in water, especially for domestic usage. All sampling stations (Figs. 6 and 7) had their bacteriological quality parameters (Heterotrophic bacteria counts, E. coli and total coliforms) above the WHO guidelines.

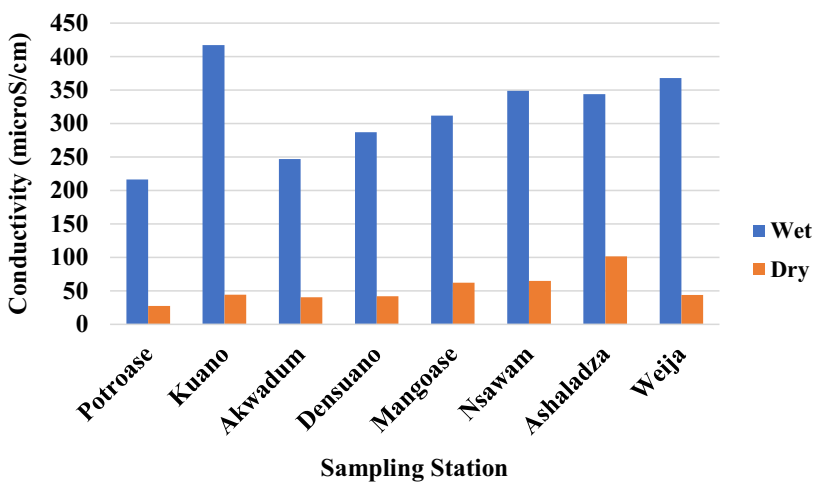

Fig. 5 Electrical conductivity for wet and dry Seasons 


\section{Heterotrophic Bacteria Count $\quad$ Total Coliform $\quad$ E. Coli}

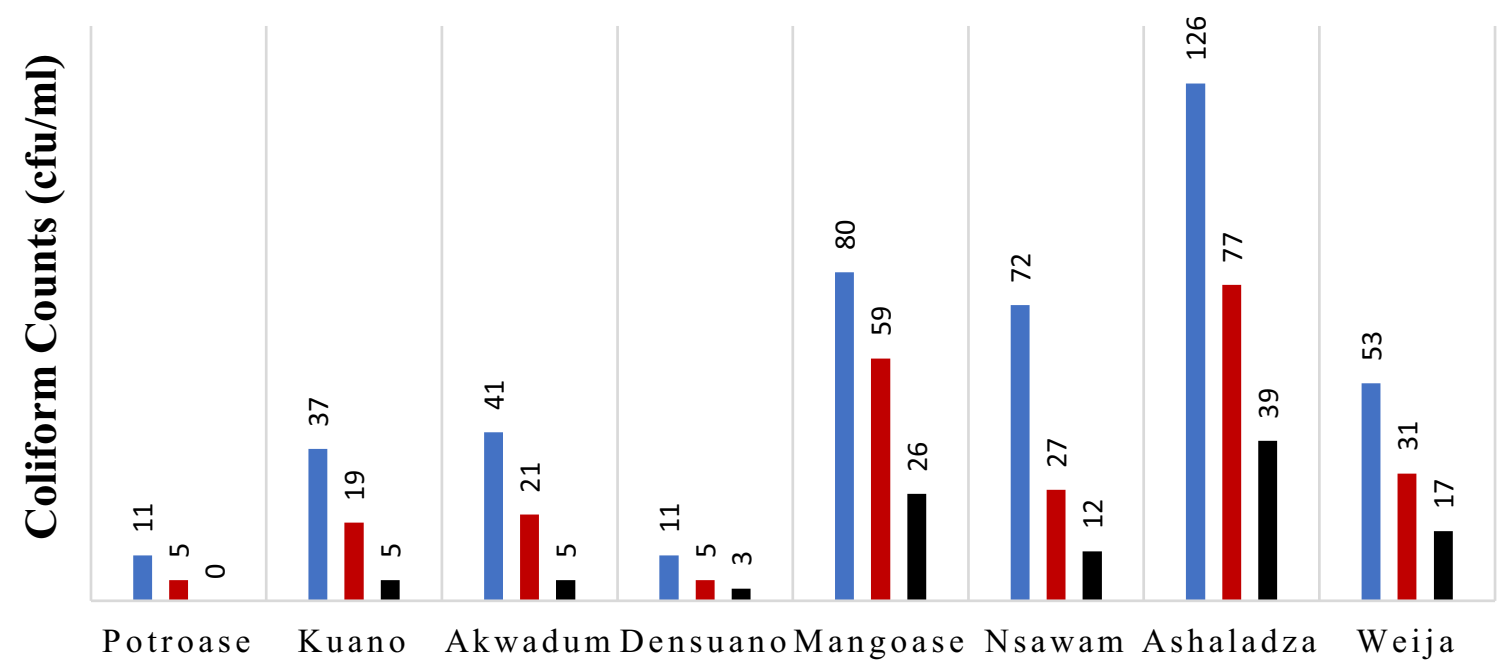

Sampling Station

Fig. 6 Bacteriological quality for dry season

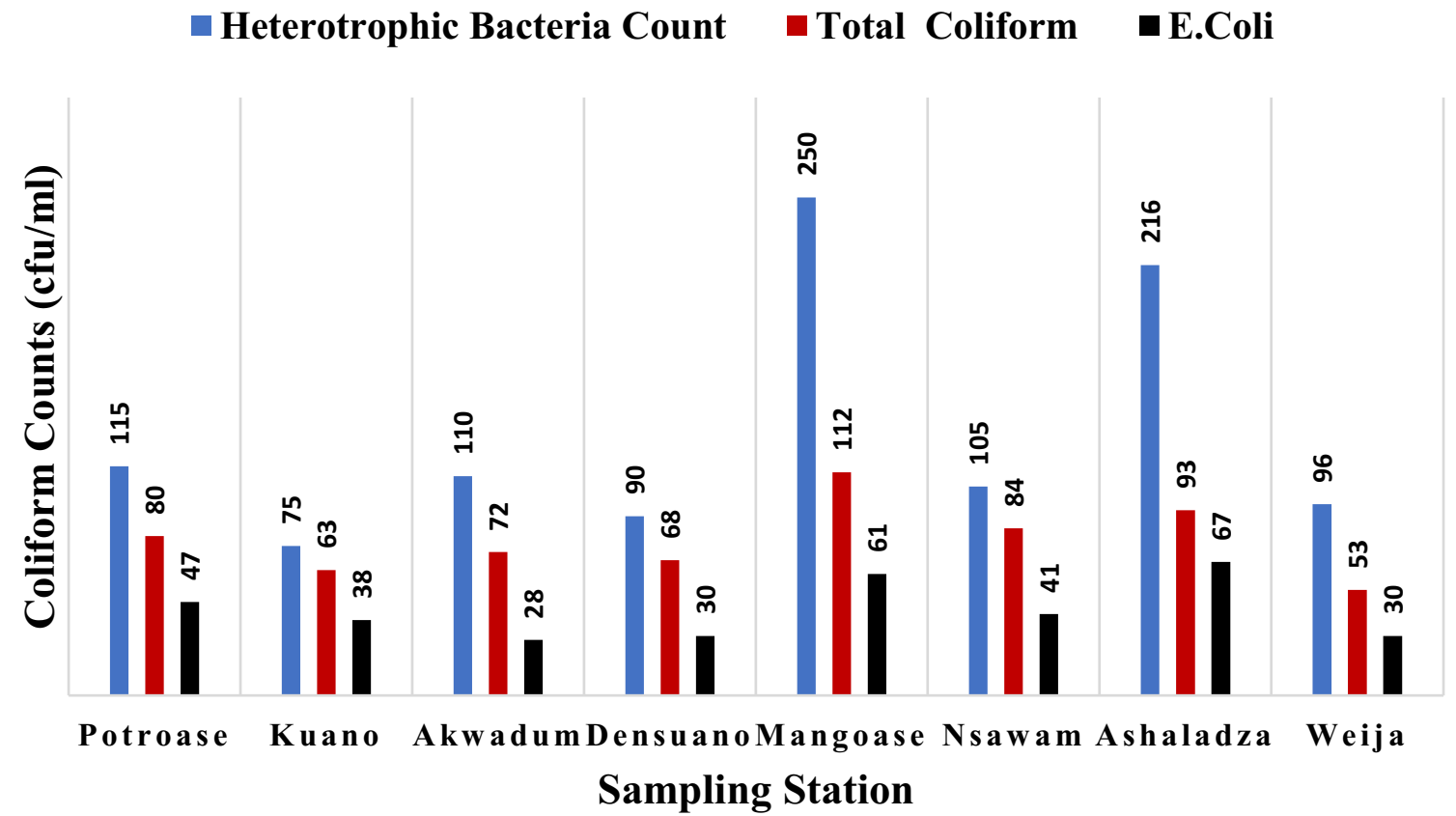

Fig. 7 Bacteriological quality for wet season

Exception can be made for Potroase whose dry season E. coli level was suitable by the WHO guidelines. It can be deduced from Fig. 6 that Ashaladza reported higher levels of bacteriological parameters. Meanwhile, Mangoase (midstream sampling station) reported high levels of bacteriological parameters (Fig. 7) during the wet season.

The water quality index for the Densu river was calculated using parameters displayed in Table 2. Based on the sample calculation shown in Table 2, the WQI for both dry and wet seasons is calculated and plotted (Fig. 8).

Based on the WQI values (Fig. 8), the average water quality for dry season sampling period was 61.87 representing Medium quality. The wet season sampling period had an average of 60.72 denoting Medium quality. These results attest to the fact that the average water quality of Densu river is Medium based on the WQI indices. 
Table 2 Wet season water quality index for Potroase

\begin{tabular}{lllll}
\hline Parameters & Raw results & $Q$-values & Weighing & Total value \\
\hline Dissolved oxygen & 5 & 50 & 0.17 & 8.5 \\
Faecal coliform & 47 & 53 & 0.16 & 8.48 \\
pH & 7.1 & 90 & 0.11 & 9.9 \\
Temperature & 26.9 & 13 & 0.11 & 1.43 \\
Total phosphate & 5 & 13 & 0.1 & 1.3 \\
Nitrate & 0.5 & 97 & 0.1 & 9.7 \\
Turbidity & 3.8 & 88 & 0.08 & 7.04 \\
Biochemical oxygen demand & 0.5 & 98 & 0.11 & 10.78 \\
Total solids & 109.23 & 83 & 0.07 & 5.81 \\
Water quality index & & & & 62.94
\end{tabular}

The WQI for Potroase, Kuano, Akwadum and Densuano had their wet season values being lower than the dry season results. These results attest to the fact that the main occupation of the upstream communities was farming. The farmers mainly engage in rainfed agricultural practices; hence, the use of agro-chemicals and farming inputs tend to lead to the decline in water quality.

\section{Principal component analysis}

The PCA was treated to reconnoitre the origins of pollutants by manipulating the dataset to obtain the most critical influencing factors. The varimax rotation method was used to further determine the factor variables with slight significance. The dataset was tested using the Kaiser-Meyer-Olkin (KMO) sphericity test.

The initial results of PCA, comprising the eigenvalues, variance, and cumulative values for both dry (Table 3 ) and wet (Table 4) seasons showed six (6) main components. The six (6) PCs with their cumulative eigenvalues were accounting for more than $97 \%$ in the dry season, whilst the six PCs accounted for about $98 \%$ in the wet season.

PC1-PC4 explains a cumulatively, $80.61 \%$ of the total variance in water quality during the dry season. PC1-PC4 explains $84.36 \%$ of the total variance in water quality during the wet season.

\section{PC analysis for dry season}

PC1 for dry season had strong positive loadings of conductivity (0.991), TDS (0.991), total hardness (0.760), calcium hardness (0.600), chloride (0.816), calcium (0.700), magnesium (0.647), total coliforms (0.857), E. coli (0.873) and heterotrophic bacteria (0.923). These results show that electrical conductivity, TDS and the bacteriological parameters greatly influenced the quality of the river.

Some moderate loadings such as dissolved oxygen (0.592), BOD (0.426), turbidity (0.446) and total suspended

\begin{tabular}{lrrl}
\hline Component & \multicolumn{3}{l}{ Initial eigenvalues } \\
\cline { 2 - 4 } & \multicolumn{1}{l}{ Total } & \% of variance & Cumulative \% \\
\hline 1 & 11.093 & 33.614 & 33.614 \\
2 & 8.381 & 25.398 & 59.012 \\
3 & 4.191 & 12.701 & 71.713 \\
4 & 4.175 & 12.651 & 84.364 \\
5 & 2.798 & 8.480 & 92.844 \\
6 & 1.619 & 4.905 & 97.749 \\
7 & 0.743 & 2.251 & 100 \\
\hline
\end{tabular}


solids (TSS) (0.546) were recorded. There were some negative loadings such as Nitrate-nitrogen (-0.384), nitrite $(-0.574)$ and ammonia-nitrogen $(-0.532)$.

PC2 has negative loadings for colour (-0.571), turbidity (-0.635), BOD (-0.720), DO (-0.347), TSS (-0.676), copper (-0.555), manganese (-0.659) and chromium (0.747). There were positive loadings for total iron (0.596), cadmium (0.625), arsenic (0.625) and mercury (0.625). PC2 highlighted the heavy metals that were dominant in the samples.

PC3 has positive loadings for calcium hardness (0.537), cadmium (0.611), arsenic (0.611) and mercury (0.611). There were negative loadings for phosphate $(-0.744)$, Nitrate-nitrogen $(-0.633)$ and ammonia-nitrogen $(-0.677)$. PC3 characterises the organic irons generated mainly from agricultural activities.

PC4 has positive loadings for magnesium hardness (0.563), copper (0.501), manganese (0.536) and negative loadings for DO $(-0.567)$, zinc $(-0.504)$ and nitrite $(-0.503)$. PC4 depicted the hardness parameters of the Densu river.

PC5 has significant loading for total alkalinity $(-0.808)$ and cyanide (0.904). For PC5, traces of cyanide ions leached from the geological formations were prominent in this component. PC6 has loadings for turbidity (0.522), total iron (0.513) and nitrite (0.547). PC6 shows the parameters that influence the colour of the Densu river.

The varimax rotation results indicated that for $\mathrm{PC} 1$, the conductivity (0.888), TDS (0.888), chloride (0.916), sulphate (0.919), total coliform (0.928), E. coli (0.936) and heterotrophic bacteria count (0.919) were the strong positive loadings identified.

PC2 indicated that colour (0.930), turbidity (0.807), TSS (0.826) and copper (0.934) were the strong positive loadings. PC3 had the following loadings identified pH $(-0.895)$, magnesium hardness (0.841) and magnesium (0.841). PC4 was predominantly heavy metals being the parameters with the strong loadings_cadmium (0.949), arsenic (0.949) and mercury (0.949).

PC5 designated ammonia-nitrogen $(-0.944)$ as a strong loading even though it is negative. PC6 reported that total alkalinity showed a strong positive loading (0.952).

\section{PC analysis for wet season}

PC1 for dry season had strong positive loadings of colour $(0.842)$, turbidity $(0.846)$, total hardness $(0.802)$, calcium hardness (0.915), calcium (0.915), Nitrate-nitrogen (0.845), nitrite (0.976), total coliforms (0.736), E. coli (0.544) and heterotrophic bacteria (0.597). These results show that the hardness of the Densu river during the wet season was influenced mainly by the presence of calcium ions.

PC2 has negative loadings for $\mathrm{pH}(-0.832)$, conductivity $(-0.630)$, TDS $(-0.635)$, magnesium $(-0.856)$, chloride
$(-0.596)$. Some positive loadings of PC2 were phosphate $(-0.802)$, total iron $(0.773)$, total coliform $(0.553)$, E coli $(0.595)$ and heterotrophic bacteria count $(0.505)$.

PC3 exhibited positive loadings for sulphate (0.952), TDS (0.506), conductivity (0.505), DO (0.706) and cadmium (0.771). PC4 showed positive loadings for temperature $(0.897)$, total alkalinity $(0.611)$, chloride $(0.606)$ and E. coli (0.515).

PC5 has significant loading for zinc (0.525) and negative loading for arsenic $(-0.637)$. PC6 did not show any loading above 0.500 .

The varimax rotation results indicated that for $\mathrm{PC} 1$, colour (0.923), turbidity (0.0.922), copper (0.939), total hardness $(0.760)$, calcium hardness $(0.848)$, calcium ions $(0.848)$ and nitrite $(0.848)$ were the strong positive loadings identified.

PC2 indicated that $\mathrm{pH}(0.931)$, magnesium hardness (0.898) and magnesium ions (0.900) were the strong positive loadings. Meanwhile, E. coli showed a negative moderate loading $(-0.503)$. PC3 had the following loadings identified $\mathrm{pH}(-0.895)$, magnesium hardness $(0.841)$ and magnesium (0.841). PC4 reported strong loadings for conductivity (0.916), TDS (0.911), total alkalinity (0.945) and chloride ions (0.619).

PC5 designated dissolved oxygen (0.981), sulphate ions (0.760), cadmium ions (0.762) and mercury (0.679) as a strong positive loading. PC6 reported zinc ions (0.951) and ammonia nitrogen ions (0.561) the main strong positive loading.

\section{Cluster analysis}

Spatial cluster analysis (CA) was applied to assemblage the sampling stations with comparable water quality physiognomies. A dendrogram (Fig. 9) produced by CA grouped the eight (8) sampling stations into three (3) clusters.

The grouping of the monitoring stations was based on statistically significant clusters in a distant connection $\left(D_{\text {link }} / D_{\max }\right) \times 100$. Hierarchical clustering was achieved consistent with Ward's method as well as a squared Euclidian distance (Varol et al. 2011; Hamil et al. 2013; Fathi et al. 2018).

The CA results were very substantial, because the created clusters shared similar characteristic features in addition to land use patterns.

During the wet season, the clusters identified comprise Cluster 1 that includes two locations (Ashaladza and Mangoase). These two stations have agricultural activities being dominant occupation. Cluster 2 entails three locations (Densuano, Akwadum and Potroase). These locations are part of the upstream sampling stations. There is some forest cover around these areas which serve as canopies for 
Fig. 9 Dendogram showing clustering of sampling stations Densu river water quality features

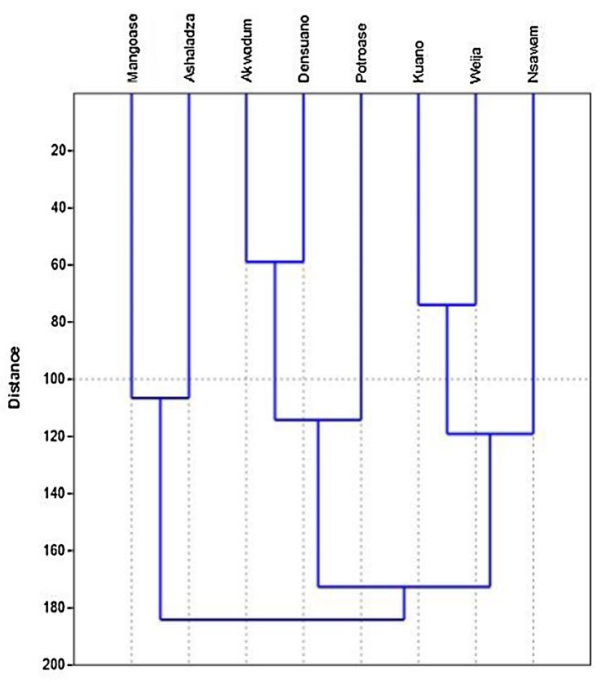

(a) Wet season

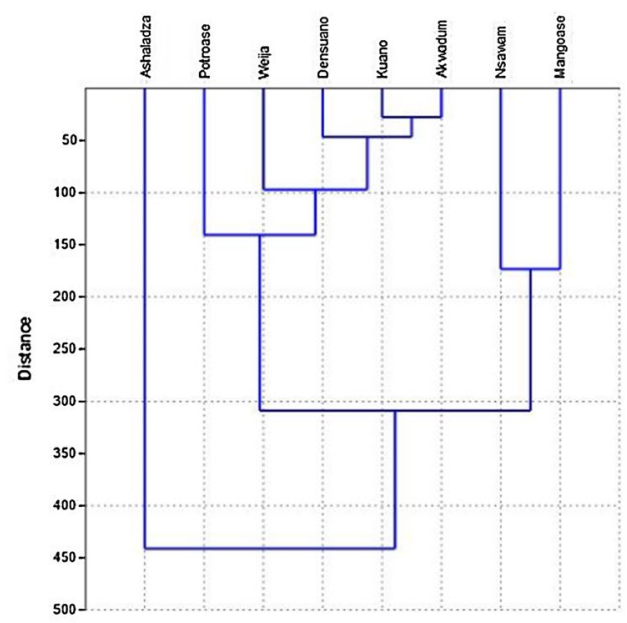

(b) Dry season the streams (Ofosu et al. 2020). Cluster 3 comprises three locations (Kuano, Nsawam and Weija). Nsawam and Weija represent heavily urbanized communities along the Densu river. Kuano is one of the built-up rural communities in the basin quite close to the Densu river.

During the dry season, the clusters noticed encompass Cluster 1 that includes one location (Ashaladza). This station has agricultural activities being dominant occupation around it. Cluster 2 involves five locations (Potroase, Densuano, Akwadum, Kuano and Weija). These locations are part of upstream sampling stations and the southernmost station (Weija).

There are some forests around the upstream areas which serve as canopies for the streams (Ofosu et al. 2020). Cluster 3 comprises two locations (Nsawam and Mangoase). Nsawam and Mangoase represent mid-stream sampling stations. Vegetable farming activities are predominant in the Nsawam and Mangoase during the dry seasons (Ayivor and Gordon 2012; Darko et al. 2013).

\section{Conclusion}

By means of WQI, the quality level of surface water in the Densu river basin was ranked. The upstream sampling stations had better quality compared to the downstream stations. This could be ascribed to seasonal variations, agricultural practices and other human-induced activities. The results of PCA revealed that six (6) factors accounted for about $97 \%$ of the dataset variances for both wet and dry sampling seasons. The PCA resulted in significant reduction of variables and also helped to extract the reasons accountable for variations in the quality of the Densu river at different sampling stations. The results of the PCA demonstrated that the level of pollution surges towards the downstream. CA clustered the sampling stations into three main clusters for both wet and dry seasons based on comparison of the Densu river quality characteristics. These results infer that domestic, agricultural and other anthropogenic pollutions caused variances in terms of water quality of the Densu river. Finally, this study has confirmed the practicality of water quality index (WQI) and multivariate statistical methods for analysis and explanation of data from surface water quality analysis.

Densu river quality monitoring schemes could be developed and applied taking into cognisance, the identified principal components, clusters of sampling stations and seasonal variations of water quality parameters.

Acknowledgements This study was supported by the Regional Water and Environmental Sanitation Centre, Kumasi (RWESCK) at the Kwame Nkrumah University of Science and Technology, Kumasi, with funding from Ghana Government and the World Bank under the Africa Centre's of Excellence project'. The views expressed in this paper do not reflect those of the World Bank, Ghana Government and KNUST.

Author contributions SAO contributed to conceptualization, design, data acquisition, data analysis and interpretation. KAA and SNO made contributions to drafting, checking graphs and revising the manuscript for final submission of the manuscript. All authors read and approved the final manuscript.

Funding The author(s) received no specific funding for this work.

Data availability The data are presented in the manuscript. The authors declare that datasets used in the manuscript are readily available upon request from the corresponding author. 


\section{Declarations}

Conflict of interest The authors declare that they have no conflict of interest.

Open Access This article is licensed under a Creative Commons Attribution 4.0 International License, which permits use, sharing, adaptation, distribution and reproduction in any medium or format, as long as you give appropriate credit to the original author(s) and the source, provide a link to the Creative Commons licence, and indicate if changes were made. The images or other third party material in this article are included in the article's Creative Commons licence, unless indicated otherwise in a credit line to the material. If material is not included in the article's Creative Commons licence and your intended use is not permitted by statutory regulation or exceeds the permitted use, you will need to obtain permission directly from the copyright holder. To view a copy of this licence, visit http://creativecommons.org/licenses/by/4.0/.

\section{References}

Abbasi T, Abbasi SA (2012) Water quality indices. Elsevier

Abyaneh MR et al (2018) A critical review on the application of the National Sanitation Foundation water quality index. Environ Pollut 244:575-587. https://doi.org/10.1016/j.envpol.2018.10.076

Adank, M. et al. (2011) Towards integrated urban water management in the Greater Accra Metropolitan Area Current status and strategic directions for the future. Accra, Ghana. Available at: http:// switchurbanwater.lboro.ac.uk/outputs.

Adomako D (2010) Geochemistry and recharge studies in the Densu River Basin of Ghana using classical hydrological method numerical modelling and tracer techniques. University of Ghana

Adomako D et al (2011a) Geochemical and isotopic studies of groundwater conditions in the Densu River Basin of Ghana. Environ Earth Sci 62(07):1071-1084. https://doi.org/10.4236/jwarp.2011. 37065

Adomako D et al (2011b) Hydrogeochemical evolution and groundwater flow in the Densu River Basin, Ghana. J Water Resour Prot 03(07):548-561. https://doi.org/10.4236/jwarp.2011.37065

Akoteyon I et al (2011) Determination of water quality index and suitability of Urban River for municipal water supply in Lagos-Nigeria. Eur J Sci Res 54(2):263-271

Alfa BA (2010) Distributed numerical modelling of hyrologica/hydrogeological processed in the Densu Basin. University of Ghana

Alfa B et al (2011) Rainfall and water resources of a coastal Basin of Ghana. J Hydrol Eng 16(4):316-323. https://doi.org/10.1061/ (ASCE)HE.1943-5584

Amoako J et al (2010) Water quality characteristics of Densu River basin in south-east Ghana. Water Sci Technol 61(6):1467-1477. https://doi.org/10.2166/wst.2010.012

Anteneh Y, Zeleke G, Gebremariam E (2018) 'Assessment of surface water quality in Legedadie and Dire catchments, Central Ethiopia, using multivariate statistical analysis', Acta Ecologica Sinica. Ecol Soc China 38(2):81-95. https://doi.org/10.1016/j.chnaes. 2017.05.005

Antwi-Agyakwa KT (2014) Assessing the effect of land use land cover change on Weija catchment. Kwame Nkrumah University of Science and Technology

Arslan O (2009) A GIS-based spatial-multivariate statistical analysis of water quality data in the Porsuk river, Turkey. Water Qual Res J Can 44(3):279-293

Asamoah, I., Jacobi, S. and Alfa, B. (2008) 'Integrated water resources management plan for Densu River Basin, Ghana', 33rd WEDC
International Conference, Accra, Ghana. Available at: http:// scholar.google.com/scholar?hl=en\&btnG=Search\&q=intitle: Integrated+water+resources+management+plan+for+Densu+ River+Basin+,+Ghana\#0.

Asante K, Quarcoopome T, Amevenku F (2008) Water quality of the Weija Reservoir after 28 years of impoundment. West Afr J Appl Ecol 13:8. https://doi.org/10.4314/wajae.v13i1.40588

Attua EM, Ayamga J, Pabi O (2014) Relating land use and land cover to surface water quality in the Densu River basin Ghana. Int J River Basin Manag. https://doi.org/10.1080/15715124.2014.880711

Ayivor JS, Gordon C (2012) Impact of land use on river systems in Ghana. West Afr J Appl Ecol 20(3):83-95

Badalians Gholikandi G et al (2011) 'Application of multivariate statistical techniques for surface water quality assessment: case study of Karaj River, Iran. WIT Trans Ecol Environ 145:361-370. https:// doi.org/10.2495/WRM110311

Bidhendi ME et al (2013) Evaluation of spatial and seasonal variations in surface water quality using multivariate statistical techniques. Int J Environ Sci Technol 6(3):467-476. https://doi.org/10.1007/ bf03326086

Bouckaert F et al (2018) Improving the role of river basin organisations in sustainable river basin governance by linking social institutional capacity and basin biophysical capacity. Curr Opin Environ Sustain 33:70-79. https://doi.org/10.1016/j.cosust.2018.04.015

Bouguerne A et al (2017) Assessment of surface water quality of Ain Zada dam (Algeria) using multivariate statistical techniques. Int J River Basin Manag 15(2):133-143. https://doi.org/10.1080/15715 124.2016.1215325

Darko HF, Ansa-asare O, Paintsil A (2013) A number description of Ghanaian water quality-A case study of the Southwestern and Coastal Rivers Systems of Ghana. J Environ Prot 4:1318-1327

Dharmendra S et al (2018) Appraisal of temporal variation of water quality status in terms of Water Quality Index (WQI) at Paraduo Port, India. Res J Chem Environ 22(12):38-48

Easton ZM et al (2007) Identifying dissolved phosphorus source areas and predicting transport from an urban watershed using distributed hydrologic modeling. Water Resour Res 43(11):1-16. https:// doi.org/10.1029/2006WR005697

Effendi H, Romanto YW (2015) Water quality status of Ciambulawung river, Banten Province, based on pollution index and NSF-WQI. Procedia Environ Sci 24:228-237. https://doi.org/10.1016/j. proenv.2015.03.030

Emami F, Koch M (2018) Methods to predict hydrologic responses to climate change in the Zarrine River Basin, Iran. Climate 6(30):1-26. https://doi.org/10.3390/cli6020030

Ewaid SH, Abed SA (2017) Water quality index for Al-Gharraf River, southern Iraq. Egypt J Aquat Res 43(2):117-122. https:// doi.org/10.1016/j.ejar.2017.03.001

Fathi E, Zamani-Ahmadmahmoodi R, Zare-Bidaki R (2018) Water quality evaluation using water quality index and multivariate methods, Beheshtabad River, Iran. Appl Water Sci 8(210):1-6. https://doi.org/10.1007/s13201-018-0859-7

Fathy SAH et al (2012) Application of principal component analysis for developing water quality index for selected coastal areas of Alexandria Egypt. Resour Environ 2(6):297-305. https://doi. org/10.5923/j.re.20120206.08

Fitch, P. et al. (2016) Integrated groundwater data management, Integrated Groundwater Management: Concepts, Approaches and Challenges. https://doi.org/10.1007/978-3-319-23576-9_ 26.

Garcia, C. A. B. et al. (2017) 'Assessment of water quality using principal component analysis: a case study of the açude da Macela - Sergipe - Brazil', in XVI World Water Congress, International Water Resources Association (IWRA) Cancun, Quintana Roo, Mexico. 29th May-3rd June, 2017, pp. 1-11. doi: https://doi.org/ 10.3103/S1063455X10040077.

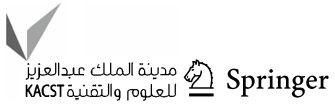


Gomes AI et al (2014) Optimization of river water quality surveys by multivariate analysis of physicochemical, bacteriological and ecotoxicological data. Water Resour Manag 28(5):1345-1361. https://doi.org/10.1007/s11269-014-0547-9

Hamil, S. et al. (2013) A Multivariate Analysis of Water Quality in Lake Ghrib, Algeria, Advances in Science, Technology \& Innovation, (August), pp. 805-807.

Hinrichsen D, Tacio H (2002). The coming freshwater crisis is already here. The linkages between population andwater. Woodrow Wilson International Center for Scholars, Washington, DC. Retrieved from http://www.wilsoncenter.org/topics/pubs/popwawa2.pdf.

Hoque MMM et al (2013) Assessment of some water quality parameters of Bansi River in monsoon and winter seasons. J Environ Sci Nat Resour 5(2):53-57. https://doi.org/10.3329/jesnr.v5i2.14601

Huang C et al (2018) Detecting, extracting, and monitoring surface water from space using optical sensors: a review. Rev Geophys 56(2):333-360. https://doi.org/10.1029/2018RG000598

Huang F et al (2010) Spatial variation and source apportionment of water pollution in Qiantang River (China) using statistical techniques. Water Res 44(5):1562-1572. https://doi.org/10.1016/j. watres.2009.11.003

Kanianska R (2015) 'Agriculture and Its Impact on land-use environment, and ecosystem services.' Intech Open 2:64. https://doi.org/ $10.5772 / 63719$

Kannel PR et al (2007) Application of water quality indices and dissolved oxygen as indicators for river water classification and urban impact assessment. Environ Monit Assess 132(1-3):93-110. https://doi.org/10.1007/s10661-006-9505-1

Kasei RA, Barnabas A, Boateng A (2014) The Nexus of changing climate and impacts on rainfed water supply and fresh water availability for the inhabitants of Densu Basin and Parts of Accra Ghana, West Africa. J Environ Earth Sci 4(20):84-96

Kebede YK, Kebedee T (2012) Application of principal component analysis in surface water quality monitoring. In: Sanguansat $P$ (ed) Principal component analysis-Engineering applications. InTech Publishers

Kengnal P et al (2015) Multivariate analysis for the water quality assessment in rural and urban vicinity of Krishna river (India). Asian J Water Environ Pollut 12(2):73-80

Khalil B, Ouarda TBMJ (2009) Statistical approaches used to assess and redesign surface water-quality-monitoring networks. J Environ Monit 11(11):1915-1929. https://doi.org/10.1039/b909521g

Khatri N, Tyagi S (2015) Influences of natural and anthropogenic factors on surface and groundwater quality in rural and urban areas. Front Life Sci 8(1):23-39. https://doi.org/10.1080/21553769. 2014.933716

Kumar Mohapatra R, Ranjan Panda C (2017) Spatiotemporal variation of water quality and assessment of pollution potential in Paradip port due to port activities. Indian J Geo Mar Sci 46(07):1274-1286

Le TTH et al (2017) 'Multivariate statistical assessment of a polluted river under nitrification inhibition in the tropics. Environ Sci Pollut Res 24(15):13845-13862. https://doi.org/10.1007/ s11356-017-8989-2

Li Y, Xu L, Li S (2009) Water quality analysis of the Songhua river basin using multivariate techniques. J Water Resour Prot 01(02):110-121. https://doi.org/10.4236/jwarp.2009.12015

Mahapatra SS et al (2012) Prediction of water quality using principal component analysis. Water Qual Expo Health 4(2):93-104. https://doi.org/10.1007/s12403-012-0068-9

Makwe E, Chup CD (2013) Seasonal variation in physico-chemical properties of groundwater around Karu abattoir. Ethiop J Environ Stud Manag 6(5):489-497. https://doi.org/10.4314/ejesm.v6i5.6
Memon M et al (2011) Drinking water quality assessment in Southern Sindh (Pakistan). Environ Monit Assess 177(1-4):39-50. https:// doi.org/10.1007/s 10661-010-1616-z

Mena-Rivera L et al (2017) Spatial and seasonal surface water quality assessment in a tropical urban catchment: Burío river, Costa Rica. Water. https://doi.org/10.3390/w9080558

Mishra A (2010) Assessment of water quality using principal component analysis : a case study of the river Ganges. J Water Chem Technol 32(4):227-234. https://doi.org/10.3103/S1063455X1 0040077

Mitra S et al (2018) Water quality assessment of the ecologically stressed Hooghly River Estuary, India: a multivariate approach. Mar Pollut Bull 126:592-599. https://doi.org/10.1016/j.marpo lbul.2017.09.053

Moyel MS (2014) Assessment of water quality of the Shatt Al-Arab River, using multivariate statistical technique. Mesop Environ J 1(1):39-46

Mustapha, A. and Abdu, A. (2012) 'Application of principal component analysis \& multiple regression models in surface water quality assessment'. J Environ Earth Sci, 2(2): 16-24. Available at: http:// www.iiste.org/Journals/index.php/JEES/article/view/1516.

Nee-Whang BG (1999) The quality of water of the Weija Dam and the Densu River. University of Ghana

Nienie AB et al (2017) Seasonal variability of water quality by physicochemical indexes and traceable metals in suburban area in Kikwit, Democratic Republic of the Congo. Int Soil Water Conserv Res 5(2):158-165. https://doi.org/10.1016/j.iswcr.2017.04.004

Nyamekye C, Nyame FK, Ofosu SA (2016) Using geospatial information component to monitor the watersheds along the Densu Basin in Ghana. J Geogr Inf Syst 8:618-632. https://doi.org/10.4236/ jgis.2016.85051

Obeng EB (2005) Application of a hydrological model in a data-poor tropical West African catchment: a case study of the Densu Basin of Ghana. Cranfield University

Ofosu SA, Adjei KA, Odai SN (2020) Ecological vulnerability of the Densu river Basin due to land use change and climate variability. Cogent Eng 7(1):31. https://doi.org/10.1080/23311916.2020. 1735714

Oketola AA, Adekolurejo SM, Osibanjo O (2013) Water quality assessment of river Ogun using multivariate statistical techniques. J Environ Prot 4:466-479

Olsen RL, Chappell RW, Loftis JC (2012) Water quality sample collection, data treatment and results presentation for principal components analysis-Literature review and Illinois River watershed case study. Water Res 46(9):3110-3122. https://doi.org/10.1016/j. watres.2012.03.028

Osei KP, Asamoah DN, Sam IA (2016) Impact and mitigation of anthropogenic activities on the Densu River Basin. J Ghana Inst Eng 1:15-21

Ouyang Y (2005) Evaluation of river water quality monitoring stations by principal component analysis. Water Res 39(12):2621-2635. https://doi.org/10.1016/j.watres.2005.04.024

Owusu G (2012) A GIS-based estimation of soil loss in the Densu basin in Ghana. West Afr J Appl Ecol 20(2):41-51. https://doi. org/10.4314/wajae.v20i2

Parinet B, Lhote A, Legube B (2004) Principal component analysis: an appropriate tool for water quality evaluation and managementApplication to a tropical lake system. Ecol Model 178(3-4):295311. https://doi.org/10.1016/j.ecolmodel.2004.03.007

Park S, Kazama F, Lee S (2014) Assessment of water quality using multivariate statistical techniques: a case study of the Nakdong river basin, Korea. Environ Eng Res 19(3):197-203. https://doi. org/10.4491/eer.2014.008

Pullanikkatil D, Palamuleni LG, Ruhiiga TM (2015) Impact of land use on water quality in the Likangala catchment, southern Malawi. 
Afr J Aquat Sci 40(3):277-286. https://doi.org/10.2989/16085914. 2015.1077777

Rubio-Arias H et al (2012) An overall water quality index (WQI) for a man-made aquatic reservoir in Mexico. Int J Environ Res Public Health 9(5):1687-1698. https://doi.org/10.3390/ijerph9051687

Salerno F, Viviano G, Tartari G (2018) Urbanization and climate change impacts on surface water quality: Enhancing the resilience by reducing impervious surfaces. Water Res 144:491-502. https:// doi.org/10.1016/j.watres.2018.07.058

Samadi, M. T. et al. (2015) 'Survey of water quality in Moradbeik river basis on WQI index by GIS'. Environ Health Eng Manag J, 1(2): 7-11. Available at: http://www.ehemj.com/browse.php?a $\mathrm{id}=46 \&$ slc_lang $=$ en $\&$ sid $=1 \&$ printcase $=1 \& \mathrm{hbnr}=1 \& \mathrm{hmb}=1 \%$ 0Ahttp://www.ehemj.com/files/site1/user_files_cb3efc/mahanA-10-27-10-bc93b2d.pdf.

Sánchez E et al (2007) Use of the water quality index and dissolved oxygen deficit as simple indicators of watersheds pollution. Ecol Ind 7(2):315-328. https://doi.org/10.1016/j.ecolind.2006.02.005

Satterthwaite D, McGranahan G, Tacoli C (2010) Urbanization and its implications for food and farming. Philos Trans R Soc B Biol Sci 365(1554):2809-2820. https://doi.org/10.1098/rstb.2010.0136

Schep S et al (2016) The economics of the Atewa Forest Range, Ghana. Accra. https://doi.org/10.1080/07349165.1995.9726076

Şener Ş, Şener E, Davraz A (2017) Evaluation of water quality using water quality index (WQI) method and GIS in Aksu River (SWTurkey). Sci Total Environ 585-585:131-144. https://doi.org/10. 1016/j.scitotenv.2017.01.102

Shrestha S, Kazama F (2007) Assessment of surface water quality using multivariate statistical techniques: a case study of the Fuji river basin, Japan. Environ Model Softw 22(4):464-475. https:// doi.org/10.1016/j.envsoft.2006.02.001

Sickman JO, Zanoli MJ, Mann HL (2007) Effects of urbanization on organic carbon loads in the Sacramento River, California. Water Resour Res 43(11):1-15. https://doi.org/10.1029/2007WR005954

Srinivasan V et al (2012) The nature and causes of the global water crisis: syndromes from a meta-analysis of coupled human-water studies. Water Resour Res 48(10):1-16. https://doi.org/10.1029/ 2011WR011087

Tian $Y$ et al (2019) Using a water quality index to assess the water quality of the upper and middle streams of the Luanhe River, northern China. Sci Total Environ 667:142-151. https://doi.org/10.1016/j. scitotenv.2019.02.356

Tripathi M, Singal SK (2019) 'Use of principal component analysis for parameter selection for development of a novel water quality index: a case study of river Ganga India.' Ecol Indic 96:430-436. https://doi.org/10.1016/j.ecolind.2018.09.025

Usman UN et al (2014) Assessment of groundwater quality using multivariate statistical techniques in Terengganu. Sci Technol 4(3):42-49. https://doi.org/10.5923/j.scit.20140403.02

Ustaoğlu F, Tepe Y (2018) 'Water quality and sediment contamination assessment of Pazarsuyu Stream, Turkey using multivariate statistical methods and pollution indicators.' Int Soil Water Conserv Res. https://doi.org/10.1016/j.iswcr.2018.09.001
Varol M et al (2011) 'Water quality assessment and apportionment of pollution sources of Tigris River (Turkey) Using multivariate statistical techniques-A case study.' River Res Appl 7:1-11. https:// doi.org/10.1002/rra.1533

Verma RK et al (2019) 'Development of simplified WQIs for assessment of spatial and temporal variations of surface water quality in upper Damodar River Basin Eastern India.' Appl Water Sci. https://doi.org/10.1007/s13201-019-0893-0

Vörösmarty CJ et al (2010) Global threats to human water security and river biodiversity. Nature 467:555-561

Wang Y, Zhu G, Yu R (2018) Assessment of surface water quality using multivariate statistical techniques: a case study in China. Irrig Drain Syst Eng 7(3):1-7. https://doi.org/10.4172/2168-9768. 1000214

Water Resources Commission (2014) WRC Annual Report 2014. Accra, Ghana. doi: https://doi.org/10.1002/ejoc.201200111

World Health Organization (2011) Guidelines for drinking-water quality. 4th edn, Infectious Diseases in Clinical Practice. 4th edn. Available at: http://www.scopus.com/inward/record.url?eid=2s2.0-0028094972\&partnerID $=40 \& \mathrm{md} 5=2 \mathrm{ed} 703788969 \mathrm{a} 5 \mathrm{f} 8 \mathrm{~b} 257$ 5d6c937713be.

World Health Organization (2017) Guidelines for drinking-water quality: fourth edition incorporating the first addendum. WHO

World Health Organization (WHO) (2017) Water quality and healthreview of turbidity: information for regulators and water suppliers. WHO/FWC/WSH/17.01.

WRC (2007) Densu River Basin- Integrated Water Resources Management Plan. Final Draft Report, 1-32.

WRC (2014) Water Resources Commission Annual Report 2013. Accra, Ghana.

Wu Z et al (2018) Assessing river water quality using water quality index in Lake Taihu Basin, China. Sci Total Environ 612:914922. https://doi.org/10.1016/j.scitotenv.2017.08.293

$\mathrm{Xu} \mathrm{H}$ et al (2009) Anthropogenic impact on surface water quality in Taihu Lake Region, China. Pedosphere Soil Sci Soc China 19(6):765-778. https://doi.org/10.1016/S1002-0160(09)60172-7

Zeinalzadeh K, Rezaei E (2017) Determining spatial and temporal changes of surface water quality using principal component analysis. J Hydrol Reg Stud 13:1-10. https://doi.org/10.1016/j.ejrh. 2017.07.002

Zhao J et al (2011) Multivariate analysis of surface water quality in the Three Gorges area of China and implications for water management. J Environ Sci 23(9):1460-1471. https://doi.org/10.1016/ S1001-0742(10)60599-2

Zhao Z, Cui F (2009) Multivariate statistical analysis for the surface water quality of the Luan River, China. J Zhejiang Univ Sci A 10(1):142-148. https://doi.org/10.1631/jzus.a0850094

Publisher's Note Springer Nature remains neutral with regard to jurisdictional claims in published maps and institutional affiliations. 